\title{
Pesticide residues in water, sediment and fish from Tono Reservoir and their health risk implications
}

\author{
Osei Akoto ${ }^{*}$, Augustine Asore Azuure ${ }^{2}$ and K. D. Adotey ${ }^{3}$
}

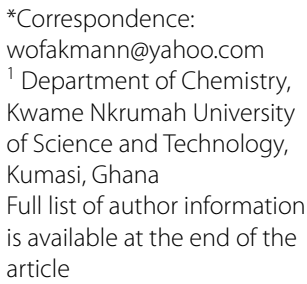

\begin{abstract}
Levels of organochlorine (OC) and organophosphorus (OP) pesticide residues in fish, sediments and water and their health risk associated with the consumption of the fish from the Tono Reservoir, Ghana were evaluated. The analytical methods included solvent extraction of the pesticide residues using ultrasound sonication and soxhlet extraction and their subsequent quantification using GC equipped with electron capture detector and pulse flame photometric detector after clean-up on activated silica gel/anhydrous sodium sulphate. A total of 29 pesticides comprising 16 OCs and 13 OPs were analyzed, out of which aldrin, $p, p^{\prime}$-DDE and $p, p^{\prime}$-DDD were detected in fish and sediment samples. The results showed that all the residues in water had their concentrations below the detection limit. Mean concentrations of organochlorine pesticide (OCP) residues in fish ranged from 0.017 to $0.17,0.043$ to $0.30,0.027$ to 0.243 and 0.097 to $0.263 \mu \mathrm{g} / \mathrm{g}$ in Sarotherodon galilaeus, Clarias anguillaris, Schilbe intermedius and Marcusenius senegalensis respectively. Mean concentrations of organophosphates pesticides ranged from 0.080 to $0.090,0.080$ to 0.087 and 0.050 to $0.063 \mu \mathrm{g} / \mathrm{g}$ in $C$. anguillaris, S. intermedius and M. senegalensis respectively. The level of chlorpyrifos in S. galilaeus was $0.160 \mu \mathrm{g} / \mathrm{g}$. Mean concentrations of OCP residue in sediments ranged from 0.047 to $0.090 \mu \mathrm{g} / \mathrm{g}$. Aldrin recorded the highest level while $p, p^{\prime}$-DDD recorded the lowest level. The mean concentrations for all the detected residues were below the WHO/FAO maximum residue limits. Health risk estimation revealed that aldrin in $M$. senegalensis had great potential for systemic toxicity to consumers.
\end{abstract}

Keywords: Bioaccumulation, Fish, Health risk, Pesticides, Toxicity

\section{Background}

Reduction of the proliferation of pest and increase in food production, has made pesticides application in agriculture inevitable (Akoto et al. 2013). Pesticides constitute one of the most hazardous groups of contaminants (Vega et al. 2005), posing potential risk to humans and other life forms (Jeyakumar et al. 2014). Thus deaths and chronic diseases worldwide are sometimes reported to have resulted from pesticide poisoning (Rigotto et al. 2013).

The occurrence of pesticides residue, especially organochlorines (OCs) in the environment is a great worry due to their tendency for long-range transport. Also their capacity to bioaccumulate in food chain poses a threat to human health and the environment 
(Chau 2005; Zhou et al. 2006; Pandit et al. 2006; Guo et al. 2008). Pesticides enter and pollute any component of the environment in a number of ways, including application, accidental spillage or through the unauthorized dumping of pesticide products or their containers (Cox 2002). Contamination of water bodies for example is a major concern for fish and other aquatic organisms such as mussels, oysters, prawns and lobsters which are major sources of protein (Essumang and Chokky 2009). Accumulation of pesticides in these organisms has become a serious public health issue worldwide. Fish are used extensively for environmental monitoring because they concentrate pollutants directly from water and diet, thus enabling the assessment of transfer of pollutants through the food web (Bruggeman 1982; Fisk et al. 1998; Lanfranchi et al. 2006; Das et al. 2002).

Fish occupy different habitats in the ecosystem and have different feeding behaviors, thereby exhibiting different profile of accumulation of contaminants such as pesticides. For example, benthic fish species are considered more prone to contamination (Yim et al. 2005; Wei et al. 2014), as they tend to accumulate sediments bound contaminants than pelagic fish (Qadir and Malik 2011; Ccanccapa et al. 2016).

Although the use of OCs and many types of OPs pesticides has been banned or severely limited in Ghana, they are still being used in many parts of the country because they are effective for agricultural and relatively inexpensive as compared to the cost of other class of pesticides (Ntow et al. 2006; Racke et al. 1997).

The Tono irrigation site near Navrongo in the Republic of Ghana, is noted for the production of large quantities of vegetables. In other to improve yield, there has been a widespread and unguided application of pesticides within the catchment by farmers. This may have resulted in runoff of pesticide residues into the reservoir thereby polluting the ecosystem and contaminating organisms living in the reservoir. It is for this reason that this study was carried out to assess the level of OC and OP residue in fish, water and sediment from the Tono Reservoir and to evaluate the potential health risk posed to consumers by these fish species.

\section{Methods}

\section{Description of study area}

The Tono Reservoir is located near the Tono Irrigation Project at Navrongo in Northern Ghana (Fig. 1). This project was established to promote the production of food crops by small-scale farmers within organized and managed irrigation schemes and covers an area of about 2490 ha (Gordon 2006; Ntow 2008). The cropping areas are divided between upland and lowland areas. Crops grown in upland plots include onions, tomatoes, millet, groundnuts, sorghum and maize while the lowland areas are earmarked for rice production. Predominant pesticides used in the area are endosulfan and chlorpyrifos which are supervised and regulated by the irrigation authorities (Ntow 2008). Some farmers also obtain cheap but effective pesticides from neighboring countries such as Togo and Burkina Faso which are not approved by the by EPA, Ghana, the pesticides regulating authority (Okoffo et al. 2016). The dam has a maximum storage capacity of about $5.0 \times 10^{5} \mathrm{~m}^{3}$ (Pelig-Ba 2011). Fishing in the reservoir is restricted officially and is only allowed on a limited scale. 


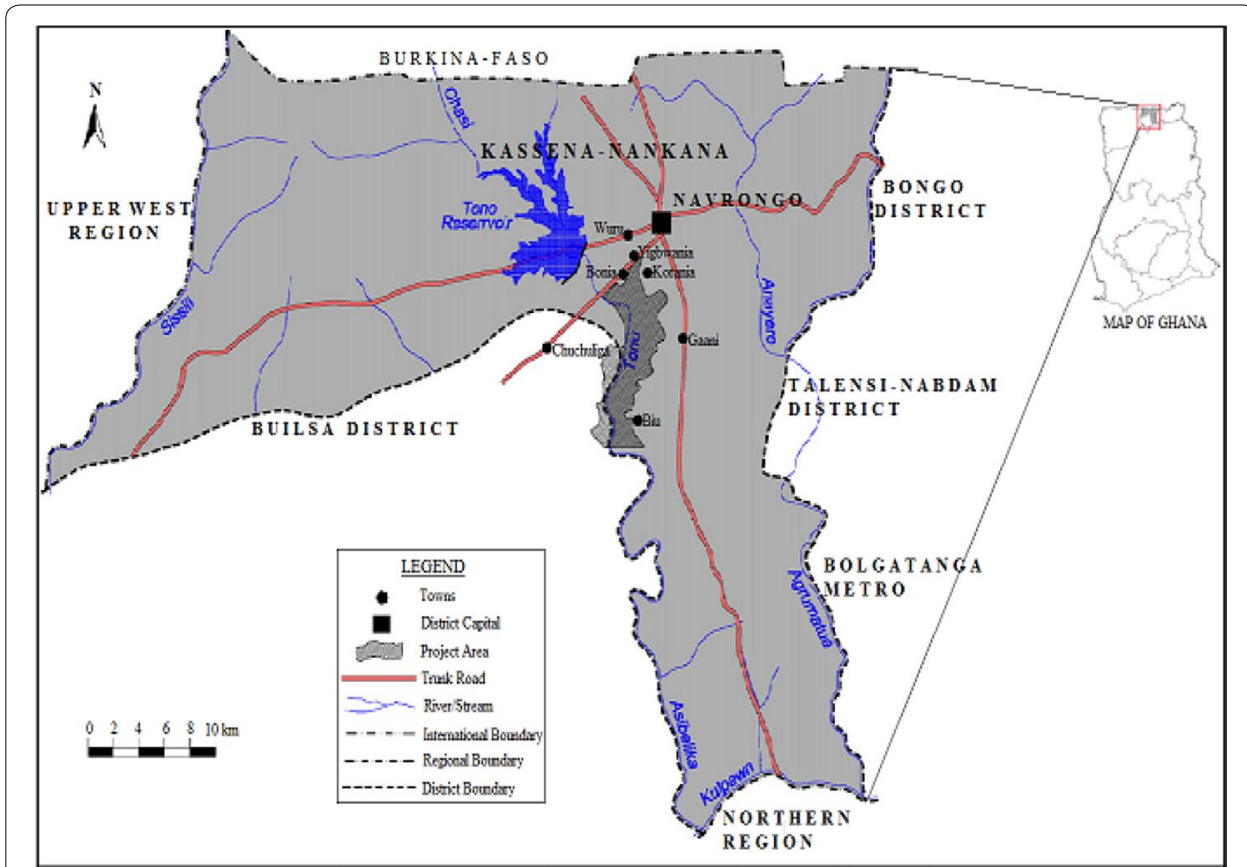

Fig. 1 Map of Kassena Nankana district in Northing Ghana showing the Tono Reservoir

\section{Sampling}

Water samples were collected from different locations within the reservoir at depth of about $1 \mathrm{~m}$ into previously cleaned $2.5 \mathrm{~L}$ plastic bottles and covered with screwed caps. A total of 12 water samples were collected from the reservoir. Sediment samples were grabbed from the bottom of the reservoir at the same locations where water samples were collected. The sediment samples were stored in clean polyethylene bags, labelled and sealed. Fish samples were purchased from fishermen at one of the reservoir's landing site. The samples were wrapped in aluminum foil, packed in clean polyethylene bags, labelled and sealed, and then transported in a thermo-insulated container with ice packs to the laboratories of Nuclear Chemistry and Environmental Research Center of the Ghana Atomic Energy Commission where they were stored at a temperature of $-20{ }^{\circ} \mathrm{C}$ until processing and analysis. All glassware and containers were washed with detergent, rinsed with purified water and acetone and kept in an oven at $180{ }^{\circ} \mathrm{C}$ for $2 \mathrm{~h}$. Sampling was conducted in two batches (August 2014 and March 2015).

Fish samples were identified at the Inland Fisheries Research Division of the Ministry of Food and Agriculture. Fish selected for this study were Catfish (Clarias anguillaris), Silver catfish (Schilbe intermedius), Trunkfish (Marcusenius senegalensis) and Mango Tilapia (Sarotherodon galilaeus). Species are among the commonly consumed fishes from the reservoir. A total of 40 fish samples comprising 10 of each species were used for this work. 


\section{Sample preparation and extraction}

Water samples were filtered through $0.45 \mu \mathrm{m}$ fiber glass filters (Whatman) to remove suspended materials. Sediment samples were air dried and then sieved through a $250 \mu \mathrm{m}$ stainless steel mechanical shaker. Fish samples were thawed, cleaned with distilled water and scales sloughed off. Muscle tissues were dissected, minced into smaller pieces and homogenized.

Extraction of pesticide residues in fish, water and sediment samples was done according to the method developed by Therdteppitak and Yammang (2002) with some modifications.

Ten (10.0) g of homogenized fish sample was placed into a $100 \mathrm{~mL}$ conical flask and $20.0 \mathrm{~g}$ of activated anhydrous sodium sulfate were added and mixed. Then $30 \mathrm{~mL}$ of 2:1 $(\mathrm{v} / \mathrm{v})$ hexane/acetone mixture were added and thoroughly mixed by shaking. The sample was then sonicated for 20 min using Bransonic Ultrasound Sonicator. The supernatant was filtered into a $250 \mathrm{~mL}$ round bottom flask. The extraction was repeated two more times and all the supernatants combined and concentrated at $40{ }^{\circ} \mathrm{C}$ to near dryness using a Vacuum Rotary Evaporator (Buchi rotavapor R-200, Buchi heating bath B-490).

\section{Extraction of pesticide residues in water samples}

About $50 \mathrm{~mL} n$-hexane was introduced into a $1 \mathrm{~L}$ separating funnel containing $100 \mathrm{~mL}$ of filtered water sample. The mixture was shaken vigorously for $5 \mathrm{~min}$ and allowed to settle. After complete separation, the organic phase was drained into a $250 \mathrm{~mL}$ conical flask while the aqueous phase was re-extracted twice with $50 \mathrm{~mL}$ of $n$-hexane. The extracted organic phase was combined and dried by passing through a glass funnel packed with activated anhydrous sodium sulfate. The organic fraction was then concentrated to near dryness using vacuum rotary evaporator at $40{ }^{\circ} \mathrm{C}$.

\section{Extraction of pesticide residues in sediments}

A 10.0 g dry sediment sample was transferred into an extraction thimble that was previously washed with $n$-hexane and acetone and oven dried. Pesticide residues in sediments were extracted with $150 \mathrm{~mL}$ of $n$-hexane/acetone mixture 4:1 v/v for $6 \mathrm{~h}$ using soxhlet extraction. The extract was then concentrated to near dryness using vacuum rotary evaporator at $40{ }^{\circ} \mathrm{C}$. Each extract was then dissolved in $10 \mathrm{~mL}$ of $n$-hexane and subjected to clean-up.

\section{Sample clean-up}

Approximately $2.5 \mathrm{~g}$ of activated silica gel was weighed and parked into a glass column which has been plugged with glass wool and $1.0 \mathrm{~g}$ of anhydrous sodium sulfate. About $10 \mathrm{~mL} n$-hexane was used to wet and rinse the column. The extract was then transferred into the column and eluted with $20 \mathrm{~mL}$ portions of hexane/acetone mixtures. The eluates were collected into a round bottomed flask and then concentrated to dryness. The residues were then dissolved in $2 \mathrm{~mL}$ of ethyl acetate and placed in a GC vial for gas chromatograph analysis. 


\section{GC analysis}

A Shimadzu 2010 GC equipped with an ECD was used to analysed the OCP residues. Separation was done on an SGE BPX-5 of $60 \mathrm{~m}$ capillary column with $0.25 \mathrm{~mm}$ internal diameter and $0.25 \mu \mathrm{m}$ film thicknesses, equipped with $1 \mathrm{~m}$ retention gap. The oven temperature was programmed as follows: initial temperature was set at $90{ }^{\circ} \mathrm{C}$ for $3 \mathrm{~min}$ and ramped at $30{ }^{\circ} \mathrm{C} / \mathrm{min}$ to $200{ }^{\circ} \mathrm{C}$ for $15 \mathrm{~min}$ and then to $265^{\circ} \mathrm{C}$ at a rate of $5{ }^{\circ} \mathrm{C} / \mathrm{min}$ for $5 \mathrm{~min}$ then to $275{ }^{\circ} \mathrm{C}$ at the rate of $3{ }^{\circ} \mathrm{C} / \mathrm{min}$ and allowed to stay for $15 \mathrm{~min}$. The injector setting is a pulsed splitless mode with a temperature of $250{ }^{\circ} \mathrm{C}$ at a pressure of 1.441 bar. Pulsed pressure was $4.5 \mathrm{bar}$, pulsed time $1.5 \mathrm{~min}$, purge flow of $55.4 \mathrm{~mL} / \mathrm{min}$ with a purge time of $1.4 \mathrm{~min}$. The detector temperature was $300{ }^{\circ} \mathrm{C}$. Nitrogen was used as carrier gas at a flow rate of $30 \mathrm{~mL} / \mathrm{min}$.

A Varian CP-3800 GC equipped with a Combi PAL Auto sampler was used to measure levels of the OP residues. The column used was a $30 \mathrm{~m} \times 0.25 \mathrm{~mm}$ internal diameter fused silica capillary coated with VF-1701 $(0.25 \mu \mathrm{m}$ film). The oven temperature was programmed as follows: initial temperature was set at $70{ }^{\circ} \mathrm{C}$ for 2 min and ramped at $25{ }^{\circ} \mathrm{C} / \mathrm{min}$ to $200{ }^{\circ} \mathrm{C}$ for $6 \mathrm{~min}$ and then to $250{ }^{\circ} \mathrm{C}$ at $20^{\circ} \mathrm{C} / \mathrm{min}$ and allowed to stay for $19 \mathrm{~min}$. The injector setting is a pulsed splitless mode at a temperature of $270{ }^{\circ} \mathrm{C}$. The detector temperature was $280^{\circ} \mathrm{C}$ in "constant makeup flow" mode. Nitrogen gas was used as carrier gas at a flow rate of $2 \mathrm{~mL} / \mathrm{min}$.

\section{Quality assurance and quality control}

Quality control measures were assured through analysis of solvent blanks, procedure blanks. All reagents used were analytical grade. Each sample was analyzed in triplicates and mean concentrations were calculated based on the number of samples that tested positive. Recalibration curves were run with each batch of samples to check their correlation coefficient which was kept above 0.98 . The results of assurance analysis indicated that pesticide determinations were within accepted levels of accuracy.

\section{Estimation of daily intake}

The estimated daily intakes (EDIs) of the various pesticides in each fish species was determined by using equation;

$$
E D I=\frac{C \times D}{B}
$$

where C, D, and B represent the concentration of pesticide residues in fish $(\mu \mathrm{g} / \mathrm{g})$ on wet weight basis, average daily intake of fish estimated at $68.5 \mathrm{~g} /$ person/day for adults (Global Fish Alliance 2010) and average body weight considered to be $60 \mathrm{~kg}$ for adults (IPCS 2006; Ge 1992).

Health risk assessment of consumers from the intake of pesticides contaminated fish was characterized by using health risk index (HI). The estimated HIs were obtained by dividing the EDI by their corresponding values of acceptable daily intakes (ADI) by WHO/FAO (FAO/WHO 2010) as shown by the equation;

$$
H R=\frac{E D I}{A D I}
$$


When the $\mathrm{HI}$ is less than 1 , the food concerned is considered acceptable. If it is greater than 1, the food concerned is considered a risk to the consumer (Darko and Akoto 2008; Akoto et al. 2015).

\section{Results and discussion}

A total of 29 pesticide residues were analyzed. It comprised $16 \mathrm{OCs}(\beta-\mathrm{HCH}, \delta-\mathrm{HCH}$, lindane, heptachlor, aldrin, dieldrin, endrin, $\alpha$-endosulphan, $\beta$-endosulphan, endosulphan sulphate, methoxychlor, fenvalerate, $\gamma$-chlordane, $p, p^{\prime}$-DDE, $p, p^{\prime}$-DDD and $p, p^{\prime}$ DDT) and 13 OPs (methamidophos, enthoprophos, phorate, dimethoate, diazinon, fonofos, pirimiphos-methyl, fenitrothion, malathion, chlorpyrifos, parathion, chlorfenvinphos and profenofos).

Three organochlorine pesticide residues comprising aldrin, $p, p^{\prime}$-DDE and $p, p^{\prime}$-DDD were detected in the fish and sediment samples analyzed. Their mean residual concentrations, ADIs, EDIs and the corresponding health hazard indices for systemic effects associated with the consumption of different fish species are summarised in Table 1.

The mean concentration of the OCPs detected in $S$. galilaeus samples were $0.017 \pm 0.012,0.170 \pm 0.001$ and $0.083 \pm 0.085 \mu \mathrm{g} / \mathrm{g}$ for aldrin, $p, p^{\prime}$-DDDE and $p, p^{\prime}-$ DDD, respectively. $p, p^{\prime}$-DDE which recorded the highest mean concentration in S. galilaeus was detected in two samples. The least mean concentration in this species was recorded by aldrin which was detected in $30 \%$ of the samples. The mean concentrations of aldrin, $p, p^{\prime}$-DDE and $p, p^{\prime}$-DDD in S. galilaeus were all below the FAO/WHO (2009) maximum residue limits (MRLs) of $0.2,1.0$ and $1.0 \mu \mathrm{g} / \mathrm{g}$ respectively.

The mean concentrations of the three OCs that were detected in $C$. anguilaris samples were $0.043 \pm 0.013,0.310 \pm 0.090$ and $0.143 \pm 0.005 \mu \mathrm{g} / \mathrm{g}$ for aldrin, $p, p^{\prime}$-DDDE and $p, p^{\prime}$-DDD, respectively (Table 1$) \cdot p, p^{\prime}$-DDE which was detected in four samples, recorded the highest mean concentration in C. anguilaris. Aldrin was detected in four samples and had the lowest mean concentration. All mean concentrations of OCPs in $C$. anguilaris were below the FAO/WHO (2009) MRLs.

Table 1 Range, mean concentrations, ADIs, EDIs of OCP residues and their $\mathrm{HI}$ associated with the consumption of fish from the Tono Reservoir $(N=10)$

\begin{tabular}{llllllll}
\hline Species of fish & Pesticide & Range & Mean \pm SD & ADI & EDI & HI & HR \\
\hline C. anguilareeis & Aldrin & $0.03-0.06$ & $0.043 \pm 0.013$ & 0.0001 & $4.91 \times 10^{-5}$ & 0.491 & No \\
& $p, p^{\prime}$-DDE & $0.20-0.42$ & $0.310 \pm 0.090$ & 0.0020 & $3.54 \times 10^{-4}$ & 0.177 & No \\
& $p, p^{\prime}$-DDD & $0.14-0.15$ & $0.143 \pm 0.005$ & 0.0020 & $1.63 \times 10^{-4}$ & 0.082 & No \\
S. galilaeus & Aldrin & $0.01-0.03$ & $0.017 \pm 0.012$ & 0.0001 & $1.94 \times 10^{-5}$ & 0.194 & No \\
& $p, p^{\prime}$-DDE & $0.17-0.17$ & $0.170 \pm 0.000$ & 0.0020 & $1.94 \times 10^{-4}$ & 0.097 & No \\
& $p, p^{\prime}$-DDD & $0.02-0.18$ & $0.083 \pm 0.085$ & 0.0020 & $9.48 \times 10^{-5}$ & 0.047 & No \\
S. intermedius & Aldrin & $0.02-0.04$ & $0.027 \pm 0.012$ & 0.0001 & $3.08 \times 10^{-5}$ & 0.308 & No \\
& $p, p^{\prime}$-DDE & $0.19-0.34$ & $0.243 \pm 0.067$ & 0.0020 & $2.77 \times 10^{-4}$ & 0.139 & No \\
& $p, p^{\prime}$-DDD & $0.02-0.14$ & $0.093 \pm 0.064$ & 0.0020 & $1.06 \times 10^{-4}$ & 0.053 & No \\
M. senegalensis & Aldrin & $0.01-0.15$ & $0.097 \pm 0.078$ & 0.0001 & $1.11 \times 10^{-4}$ & 1.107 & Yes \\
& $p, p^{\prime}$-DDE & $0.22-0.30$ & $0.263 \pm 0.033$ & 0.0020 & $3.00 \times 10^{-4}$ & 0.150 & No \\
& $p, p^{\prime}$-DDD & $0.08-0.16$ & $0.110 \pm 0.044$ & 0.0020 & $1.26 \times 10^{-4}$ & 0.063 & No
\end{tabular}


OCP residues detected in $S$. intermedius samples were aldrin, $p, p^{\prime}$-DDE and $p, p^{\prime}$ DDD at concentration $0.027 \pm 0.012,0.243 \pm 0.067$ and $0.093 \pm 0.064 \mu \mathrm{g} / \mathrm{g}$ respectively (Table 1). $p, p^{\prime}$-DDE, the most frequent residue with the highest mean concentrations of $0.243 \pm 0.067 \mu \mathrm{g} / \mathrm{g}$ occurred in 4 samples of the $S$. intermedius. The minimum residue level of $0.027 \pm 0.012 \mu \mathrm{g} / \mathrm{g}$ was recorded by aldrin detected in 3 samples.

Organochlorine pesticide residues detected in $M$. senegalensis were aldrin, $p, p^{\prime}-\mathrm{DDE}$ and $p, p^{\prime}$-DDD as presented in Table 1. $p, p^{\prime}$-DDE recorded the highest mean concentration of $0.263 \pm 0.033 \mu \mathrm{g} / \mathrm{g}$ and occurred in 4 of the samples. The mean concentrations of OCPs in M. senegalensis did not exceed the FAO/WHO (2009) MRLs.

Higher levels of DDT metabolites; $p, p^{\prime}$-DDD and $p, p^{\prime}$-DDE were recorded in the four species of fish samples. These results indicate that $p, p^{\prime}$-DDE accumulation was the highest in all the fish samples. Its highest value was observed in $C$. anguilaris at a level of $0.310 \pm 0.090 \mu \mathrm{g} / \mathrm{g}$, while the lowest mean value of $0.170 \pm 0.000 \mu \mathrm{g} / \mathrm{g}$ was observed in S. galilaeus. In a similar study, Zabik et al. (1995) found that over $80 \%$ of DDTs detected in fish samples from great lakes were $p, p^{\prime}$-DDE. The current study also agree with Kuranchie-Mensah et al. (2011) who found widespread of $p, p^{\prime}$-DDE in all fish samples from the Volta Lake in Ghana. The presence of $p, p^{\prime}$-DDE in muscle tissues of fish has also been reported from Lake Parishan in Iran by Kafilzadeh et al. (2012). The results from this study is expected because of the high lipophilic and hydrophobic nature of DDT and its metabolites $\left(p, p^{\prime}\right.$-DDD and $p, p^{\prime}$-DDE) and the possibility of being retained on the organic phase of sediment and organisms as indicated by Adeyemi et al. (2008). Again, the detection of $p, p^{\prime}-\mathrm{DDE}$ and $p, p^{\prime}$-DDD is an indication of photochemical degradation of $p, p^{\prime}$-DDT which shows past use of $p, p^{\prime}$-DDT within the Tono catchment. Thus farmers within the Tono irrigation site have probably stopped using DDT on their farms.

Aldrin was detected in all the species of fish analyzed. The maximum mean concentration of aldrin occurred in M. senegalensis while the minimum level was found in $S$. galilaeus. Research has shown that aldrin is readily converted into dieldrin in plant and animal tissues and also, aldrin photolysis to dieldrin in the environment (Akan et al. 2014). It can therefore be stated that the presence of aldrin without it's metabolite in this study was an indication of recent use of aldrin within the Tono catchment even though the use of this pesticide is completely banned in Ghana.

Clarias anguillaris recorded the highest total mean residues of the OCPs followed by $M$. senegalensis and S. intermedius whilst the least was recorded in S. galilaeus. The differences in concentration in the fishes are probably due to different feeding habits. Carnivorous fish might bioaccumulate OC pesticides more by eating other fishes, while the constant contact of bottom feeders like M. senegalensis with sediments allows their continuous exposure to the adsorbed pesticides. C. anguillaris and S. intermedius are carnivorous fishes which are high in the trophic level and are thus potentially prone to biomagnification as compared to S. galilaeus (Kuranchie-Mensah et al. 2011) which feeds primarily on phytoplankton and algae. In a study by (Kent and Johnson 1979) C. anguilaris which is a bottom feeder, recorded the highest level of OC pesticides in the American Fall Reservoir. Again, data from the National Contaminant Biomonitoring Program in major US Rivers and the Great lakes found no difference between OC pesticide residues in bottom feeders and predatory fish (Caldas et al. 1999). A similar observation was also recorded in this study, where the benthic feeders $M$. senegalensis 
and predator S. intermedius contained higher concentrations of total OC residues than the herbivore S. galilaeus. Studies have shown that species-specific differences and feeding habit of fishes also influence the variation in accumulation pattern of OCP residues among species (Muralidharan et al. 2009).

\section{OP pesticides residue levels in fish samples from Tono Reservoir}

Mean residual concentrations, EDI and health risk estimation for OPs in the fish samples from the Tono Reservoir are presented in Table 2. Out of the thirteen (13) OPs analysed only chlorpyrifos and pirimiphos-methyl were detected in fish samples. Mean concentrations of chlorpyrifos in muscle tissues of $C$. anguilaris was $0.093 \pm 0.074 \mu \mathrm{g} / \mathrm{g}$ while a mean concentration of $0.080 \pm 0.066 \mu \mathrm{g} / \mathrm{g}$ was recorded for pirimiphos-methyl in $50 \%$ of the samples. Chlorpyrifos and pirimiphos-methyl residues were detected in S. intermedius and M. senegalensis samples. Chlorpyrifos recorded mean concentrations of $0.087 \pm 0.038$ and $0.050 \pm 0.057 \mu \mathrm{g} / \mathrm{g}$ in S. intermedius and M. senegalensis respectively. Pirimiphos-methyl recorded a mean concentration of $0.080 \pm 0.046 \mu \mathrm{g} / \mathrm{g}$ in S. intermedius and a mean concentration of $0.063 \pm 0.045 \mu \mathrm{g} / \mathrm{g}$ in M. senegalensis. Chlorpyrifos was the only residue found in S. galilaeus samples from the Tono Reservoir at a mean level of $0.160 \pm 0.037 \mu \mathrm{g} / \mathrm{g}$. This was detected in $40 \%$ of the total samples.

Organophosphorus pesticides are much more resistant to microbial degradation and have the tendency to concentrate in lipid rich tissues of aquatic organisms (Essumang and Chokky 2009). Among the two OPs detected, chlorpyrifos recorded the highest concentration in S. galilaeus while the least value was determined in M. senegalensis. Pirimiphos-methyl was however not detected in all the samples of $S$. galilaeus. The highest mean total OP residual load was recorded in $C$. anguillaris followed by $S$. intermedius and S. galilaeus while the lowest value was recorded in M. senegalensis. The presence of the detected OP pesticides residues is evident by their use on irrigation farms around the Tono Reservoir. Organophosphorus pesticide residues were below the prescribed MRL set by FAO/WHO in all fish samples. Similar work conducted in Nigeria by Akan et al. (2014) reported significantly higher concentrations of chlorpyrifos (ranging from 0.77 to $2.22 \mu \mathrm{g} / \mathrm{g}$ ) in fish tissues than those detected in this study.

Table 2 Range, mean concentrations, ADIs, EDIs of OP pesticides residues and their HI associated with the consumption of fish from the Tono Reservoir $(N=10)$

\begin{tabular}{llllllll}
\hline Species of fish & Pesticide & Range & Mean \pm SD & ADI & EADI & HI & HR \\
\hline C. anguillaris & Chlorpyrifos & $0.01-0.15$ & $0.093 \pm 0.074$ & 0.0100 & $1.06 \times 10^{-4}$ & 0.011 & No \\
& Pirimiphos-methyl & $0.01-0.15$ & $0.080 \pm 0.066$ & 0.0200 & $9.13 \times 10^{-5}$ & 0.005 & No \\
S. intermedius & Chlorpyrifos & $0.06-0.13$ & $0.087 \pm 0.038$ & 0.0100 & $9.93 \times 10^{-5}$ & 0.010 & No \\
& Pirimiphos-methyl & $0.04-0.13$ & $0.080 \pm 0.046$ & 0.0200 & $9.13 \times 10^{-5}$ & 0.005 & No \\
M. senegalensis & Chlorpyrifos & $0.01-0.13$ & $0.050 \pm 0.057$ & 0.0100 & $5.71 \times 10^{-5}$ & 0.006 & No \\
& Pirimiphos-methyl & $0.02-0.11$ & $0.063 \pm 0.045$ & 0.0200 & $7.19 \times 10^{-5}$ & 0.004 & No \\
S. galilaeuls & Chlorpyrifos & $0.11-0.20$ & $0.160 \pm 0.037$ & 0.0100 & $1.83 \times 10^{-4}$ & 0.018 & No \\
\hline
\end{tabular}




\section{OC pesticide residues in sediments from Tono Reservoir}

Levels of OCP residues detected in surface sediment samples from Tono Reservoir are presented in Table 3. Out of 16 organochlorines analyzed, residues of three (aldrin, $p, p^{\prime}$ DDE and $p, p^{\prime}$-DDD) were detected in sediment samples with aldrin recording the highest mean residue level of $0.090 \pm 0.050 \mu \mathrm{g} / \mathrm{g}$ followed by $p, p^{\prime}$-DDE which recorded a mean concentration of $0.070 \pm 0.033 \mu \mathrm{g} / \mathrm{g} . p, p^{\prime}$-DDD recorded the lowest mean concentration of $0.047 \pm 0.028 \mu \mathrm{g} / \mathrm{g}$.

Studies have shown that OC pesticides tend to accumulate more in aquatic organisms and they substantially settle on the sediments (Akan et al. 2014). The result of this study indicates that OC pesticide residues were present in varying amounts in different species of fish and sediments sampled from Tono Reservoir. Indeed, the study has revealed that any OC pesticide present in water will preferably be adsorbed to sediment or bioaccumulate in fish due to low water solubility of OC pesticides (Caldas et al. 1999). This could probably be the reason for the absence of OCP in water samples analyzed in this study. On the contrary, work done by Pelig-Ba (2011) on unfiltered water from the Tono Reservoir revealed presence of aldrin $(0.002 \mu \mathrm{g} / \mathrm{L}), \mathrm{p}, \mathrm{p}-\mathrm{DDE}(0.002 \mu \mathrm{g} / \mathrm{L})$ and DDT $(22.4 \mu \mathrm{g} / \mathrm{L})$.

The mean concentrations of $p, p^{\prime}$-DDE and $p, p^{\prime}$-DDD determined in fish samples were higher than those present in sediments. Sediments however had higher concentrations of aldrin than fish samples except in M. senegalensis. Sediment samples also had more frequent detection of pesticides than fish samples. This contrast to findings made by Caldas et al. (1999) in which fish samples from Paranoa Lake of Brasilia in Brazil had more frequent detections of OCP residue than did sediment samples from the same lake. Kuranchie-Mensah et al. (2011) reported much higher mean concentrations of aldrin and $p, p^{\prime}$-DDE in sediments at Nsawam in Ghana from the Densu river basin than the levels determined in this study.

\section{OP pesticide residues in sediments from Tono Reservoir}

In the sediment samples, two OP pesticides residues (pirimiphos-methyl and profenofos) were detected. Pirimiphos-methyl recorded the highest mean residual value while profenofos recorded the lowest (Table 3). Pirimiphos-methyl was found in both sediments and all the fish samples analyzed except in S. galilaeus. The levels of pirimiphosmethyl in sediments were higher than the levels in the fish samples. Profenofos on the other hand was detected only in sediments. Even though chlorpyrifos was detected in the fish samples, there was no detection of chlorpyrifos in sediment samples.

Table 3 Levels of OC and OP pesticides residues in the sediments from the Tono Reservoir

\begin{tabular}{llll}
\hline Class of pesticide & Pesticide & Range & Mean \pm SD \\
\hline Organochlorines & Aldrin & $0.04-0.14$ & $0.090 \pm 0.050$ \\
& $p, p^{\prime}$-DDE & $0.01-0.11$ & $0.070 \pm 0.033$ \\
& $p, p^{\prime}$-DDD & $0.02-0.09$ & $0.047 \pm 0.028$ \\
Organophosphorus & Pirimiphos-methyl & $0.01-0.17$ & $0.104 \pm 0.052$ \\
& Profenofos & $0.01-0.15$ & $0.050 \pm 0.047$ \\
\hline
\end{tabular}


None of the two pesticides classes considered in this study was detected in the water samples. These pesticides are lipophilic and therefore insoluble in water.

\section{Potential health risk associated with the consumption of fish contaminated with OCP and OPP residues from the Tono Reservoir}

The hazard indices presented in Table 1 showed that aldrin in M. senegalensis recorded $\mathrm{HI}>1$. This shows that there is health risk associated with lifetime consumption of $M$. senegalensis from the Tono Reservoir. On the other hand, S. galilaeus, C.anguillaris and S. intermedius showed no health hazard associated with their consumption as their hazard indices for all the detected residues (aldrin, $p, p^{\prime}$-DDE and $p, p^{\prime}$-DDD) were $<1$ in spite of the presence of OCP and OPP residue in the fish.

\section{Conclusion}

The study has revealed the presence of aldrin, $p, p^{\prime}$-DDE, $p, p^{\prime}$-DDD, chlorpyrifos, pirimiphos-methyl and profenofos in fish and sediment from the Tono Reservoir but all pesticides were below detection limits in the filtered water. Concentrations of the OCP residues detected in the fish samples were higher than that in the sediments. The levels of all the pesticide residues found in this study were well below WHO/FAO values. Analysis of health risk assessment revealed that aldrin in M. senegalensis had great potential for systemic toxicity to consumers. Regular monitoring is therefore required to control the levels of pesticide residues in the reservoir.

Authors' contributions

The authors contributed equally to this study. All authors read and approved the final manuscript.

\section{Author details}

${ }^{1}$ Department of Chemistry, Kwame Nkrumah University of Science and Technology, Kumasi, Ghana. ${ }^{2}$ Department of Theoretical and Applied Biology, Kwame Nkrumah University of Science and Technology, Kumasi, Ghana. ${ }^{3}$ Nuclear Chemistry and Environmental Research Center of GAEC, Accra, Ghana.

\section{Acknowledgements}

The work was supported by the Ghana Government Research Allowance and the MSc. Fellowship by the Scholarship secretariat in Ghana. We thank the staff of the Nuclear Chemistry and Environmental Research Center of Ghana Atomic Energy Commission for their help during the chemical analysis of the samples.

\section{Competing interests}

The authors declare that they have no competing interests.

Received: 20 May 2016 Accepted: 13 October 2016

Published online: 22 October 2016

\section{References}

Adeyemi D, Ukpo G, Anyakora C, Unyimandu J (2008) Organochlorine pesticides residues in fish samples from Lagos Lagoon, Nigeria. Am J Environ Sci 4:649-653

Akan JC, Sodipo OA, Mohammed Z, Abdulrahman F (2014) Determination of organochlorine, organophosphorus and pyrethroid pesticide residues in water and sediment samples by high performance liquid chromatography (HPLC) with UV/visible detector. J Anal Bioanal Tech 5:226. doi:10.4172/2155-9872.1000226

Akoto O, Andoh H, Darko G, Eshun K, Osei-Fosu P (2013) Health risk assessment of pesticides residue in maize and cowpea from Ejura, Ghana. Chemosphere 92:67-73

Akoto O, Gavor S, Appah MK, Apau J (2015) Estimation of human health risk associated with the consumption of pesticide-contaminated vegetables from Kumasi, Ghana. Environ Monit Assess 187(5):244. doi:10.1007/ s10661-015-4471-0

Bruggeman WA (1982) Bioaccumulation and transformation of dichlorobiphenyls in fish. In: Hutzinger O (ed) The handbook of environmental chemistry, vol 2, Part B, pp 29-47

Caldas ED, Coelho R, Souza LCKR, Siba SC (1999) Organochlorine pesticides in water, sediment, and fish of Paranoá Lake of Brasilia, Brazil. Bull Environ Contam Toxicol 62:199-206 
Ccanccapa A, Masiá A, Navarro-Ortega A, Picó Y, Barceló D (2016) Pesticides in the Ebro River basin: occurrence and risk assessment. Environ Pollut 211:414-424

Chau KW (2005) Characterization of transboundary POP contamination in aquatic ecosystems of Pearl River delta. Mar Pollut Bull 51:960-965

Cox JR (2002) Pesticide residue analysis facilities: experiences from the Natural Resource Institute's Support Program. In: Hanak E, Boutrif E, Fabre P, Pineiro M (Scientific Editors) Food safety management in developing countries, Proceedings of the International Workshop, CIRAD-FAO, December 11-13, 2000. Montpellier, France

Darko G, Akoto O (2008) Dietary intake of organophosphorus pesticide residues through vegetables from Kumasi, Ghana. Food Chem Toxicol 46(12):3703-3706. doi:10.1016/j.fct.2008.09.049

Das B, Khan YSA, Das P, Shaheen SM (2002) Organochlorine pesticide residues in catfish, Tachysurus thalassinus (Ruppell, 1835) from the South Patches of the Bay of Bengal. Environ Pollut 120:255-259

Essumang DK, Chokky L (2009) Pesticide residues in the water and fish (Lagoon tilapia) samples from Lagoons in Lagoons in Ghana. Bull Chem Soc Ethiopia 23(1):19-27

FAO/WHO (2009) Food standard programme. In: Codex Alimentarius Commission, vol 9 (4), pp 149-158

FAO/WHO (2010) Pesticide residues in food and feed. Acceptable daily intake; Codex Alimentarius Commission. FAO/ WHO Food Standards, Rome

Fisk AT, Norstrom RJ, Cymbalisty CD, Muir DCG (1998) Dietary accumulation and depuration of hydrophobic organochlorines: bioaccumulation parameters and their relationship with the octanol/water partition coefficient. Environ Toxicol Chem 17:951-961

Ge KY (1992) The status of nutrient and meal of Chinese in the 1990s. Beijing People's Hygiene, Beijing

Global Fish Alliance (2010) The importance of captured fisheries in Ghana. www.globalfishalliance.org

Gordon C (2006) The multi-stakeholder consultation process for dams development in Ghana. Volta Basin Research Project, University of Ghana, Accra

Guo Y, Meng X, Tang H, Zeng EY (2008) Tissue distribution of organochlorine pesticides in fish collected from the Pearl River Delta, China: implications for fishery input source and bioaccumulation. Environ Pollut 155:150-156

IPCS (2006) Inventory of IPCS and other WHO pesticide evaluations and summary of toxicological evaluations performed by the joint meeting on pesticide residues (JMPR) through 2005. http://www.who.int/ipcs/publications/jmpr/ jmpr_pesticide/en/index.html. Accessed November 2014

Jeyakumar T, Kalaiarasi I, Rajavel AL, Anbu M, Kumar R (2014) Levels of organochlorine pesticide residues in water and sediment from selected agricultural sectors of Kanyakumari District, Tamil Nadu, India. Int J Environ Res 8(2):493-500

Kafilzadeh F, Amir HS, Malekpour R, Azad HN (2012) Determination of organochlorine pesticide residues in water, sediments and fish from Lake Parishan, Iran. World J Fish Mar Sci 4(2):150-154. doi:10.5829/idosi.wjfms.2012.04.02.56399

Kent JC, Johnson DW (1979) Organochlorine residues in fish, water, and sediment of American Falls Reservoir, Idaho. Pestic Monit J. 13(1):28-34

Kuranchie-Mensah H, Atemo SM, Maud LNP et al (2011) Determination oforganochlorine pesticide residue in sediment and water from the Densu river basin, Ghana. Chemosphere. doi:10.1016/j

Lanfranchi AL, Menone ML, Miglioranza KSB, Janiot LJ et al (2006) Striped weakfish (Cynoscion guatucupa): a biomonitor of organochlorine pesticides in estuarine and near-coastal zones. Mar Pollut Bull 52:74-80

Muralidharan S, Dhananjayan V, Jayanthi P (2009) Organochlorine pesticides in commercial marine fishes of Coimbatore, India and their suitability for human consumption. Environ Res 109:15-21

Ntow JW (2008) The use and fate of pesticides in vegetable-based agroecosystems in Ghana. PhD Dissertation submitted to Wageningen University and UNESCOIHE Institute for Water Education, p 120

Ntow WJ, Gijzen HJ, Kelderman P, Drechsel P (2006) Farmer perceptions and pesticide use practices in vegetable production in Ghana. Pest Manag Sci 62(4):356-365

Okoffo ED, Fosu-Mensah BY, Gordon C (2016) Persistent organochlorine pesticide residues in cocoa beans from Ghana, a concern for public health. Int J Food Contam 3:5. doi:10.1186/s40550-016-0028-4

Pandit GG, Sahu SK, Sharma S, Puranik VD (2006) Distribution and fate of persistent organochlorine pesticides in coastal marine environment of Mumbai. Environ Int 32:240-243

Pelig-Ba KB (2011) Levels of agricultural pesticides in sediments and irrigation water from Tono and Vea in the upper east region of Ghana. J Environ Prot 2:761-768

Qadir A, Malik RN (2011) Heavy metals in eight edible fish species from two polluted tributaries (Aik and Palkhu) of the River Chenab. Biol Trace Elem Res, Pakistan. doi:10.1007/s12011-011-9011-3

Racke KD, Skidmore MW, Hamilton DJ et al (1997) Pesticides fate in tropical soils. Pure Appl Chem 69:1349

Rigotto RM, da Silva AMC, Ferreira MJM et al. (2013) Trends of chronic health effects associated to pesticide use in fruit farming regions in the state of Ceará, Brazil. Rev Bras Epidemiol 16(3):763-773

Therdteppitak A, Yammang K (2002) Determination of organochlorine pesticides in commercial fish by gas chromatography with electron capture detector and confirmation by gas chromatography-mass spectrometry. Sci Asia 29(2003):127-134

Vega AB, Frenich AG, Vidal JLM (2005) Monitoring of pesticides in agricultural water and soil samples from Andalusia by liquid chromatography coupled to mass spectrometry. Anal Chim Acta 538:117-127

Wei Y, Zhang J, Zhang D, Tu T, Luo L (2014) Metal concentrations in various fish organs of different fish species from Poyang Lake, China. Ecotoxicol Environ Saf 104:182-188

Yim UH, Hong SH, Shim WJ, Oh JR (2005) Levels of persistent organochlorine contaminants in fish from korea and their potential health risk. Arch Environ Contamin Toxicol 48(3):358-366

Zabik ME, Zabik MJ, Booren AM et al (1995) Pesticides and total polychlorinated biphenyls residues in raw and cooked walleye and white bass harvested from the Great Lakes. Bull Environ Contam Toxicol 54:396-402

Zhou R, Zhu L, Yang K, Chen Y (2006) Distribution of organochlorine pesticides in the Tonghui River of Beijing, China. Environ Pollut 130:249-261 